\title{
İç Hastalıkları Kliniğinde Tedavi Edilen Geriatrik Hastaların Değerlendirilmesi
}

\author{
Evaluation of Geriatric Patients Treated in Internal Medicine Clinic \\ Türkan Paşalı Kilit ${ }^{1}$, Kevser Onbaşı ${ }^{2}$, Aydan Akalın ${ }^{3}$ \\ ${ }^{1}$ Kütahya Sağlık Bilimleri Üniversitesi, İç Hastalıkları Anabilim Dalı, Kütahya, Türkiye \\ ${ }^{2}$ Kütahya Sağlık Bilimleri Üniversitesi, Endokrinoloji Bilim Dalı, Kütahya, Türkiye, \\ ${ }^{3}$ Kütahya Sağlık Bilimleri Üniversitesi, Evliya Çelebi Eğitim ve Araştırma Hastanesi, İç Hastalıkları Kliniği, Kütahya, Türkiye \\ Yazıșma Adresi / Correspondence: \\ Türkan Paşalı Kilit \\ Kütahya Sağılk Bilimleri Üniversitesi, Evliya Çelebi Eğitim ve Araştırma Hastanesi, 43050, Kütahya, Türkiye \\ T: $+905325499800 \quad$ E-mail : turkandr@yahoo.com \\ Geliş Tarihi / Received : 27.04.2021 Kabul Tarihi / Accepte: 22.08.2021 \\ Orcid : \\ Türkan Paşalı Kilit https://orcid.org /0000-0003-1126-7336 \\ Kevser Onbaşı https://orcid.org / 0000-0003-2230-9263 \\ Aydan Akalın https://orcid.org / 0000-0002-3094-127X \\ ( Sakarya Tip Dergisi / Sakarya Med J 2021, 11(3):507-515) DoI: 10.31832/smj.927899
}

\footnotetext{
$\ddot{O} z$

Amaç İç Hastalıları Kliniğinde tedavi gören geriatrik hastaların demografik özelliklerini, hastaneye yatı̧̣ nedenlerini, kronik hastalklarını ve laboratuvar sonuçlarını değerlendirmeyi amaçladık.

Gereç ve Çalıșmaya Ocak 2015 ile Aralık 2017 tarihleri arasında İç Hastalıkları Kliniğinde yatarak tedavi gören 65 yaş ve üzeri toplam 370 hasta alındı. Hastaların demografik verileri Yöntemler ve laboratuvar sonuçları retrospektif olarak incelendi.

Bulgular En sık hastaneye yatış nedenleri sırasılyla hiperglisemi (\%29,7), anemi (\%15,1), pnömoni (\%10,8), akut böbrek yetmezliği (\%7) ve beslenme bozukluğuydu (\%6,8). Hastane içi mortalite oranı \%3,5'du ve ölen hastalarda en sık yatış nedeni beslenme bozukluğuydu $(\% 38,5)$. Anemi nedeniyle hastaneye yatırılan 56 hastada en ssk anemi nedeni demir eksikliği anemisiydi $(\% 62,5)$. En sık görülen kronik hastalıklar sırasıyla hipertansiyon $(\% 72,4)$, diabetes mellitus $(\% 62,4)$ ve anemiydi (\%46,5). Hastaların \%15,1'ine girișimsel işlem yapıldı. En sık yapılan girişimsel işlem alt ve üst gastrointestinal sistem endoskopisiydi $(n=24, \% 6,5)$. Polifarmasi oranı tüm yaş gruplarında $\% 75,7$ olup 65-79 yaş grubunda $\% 77,9,80$ yaș ve üzeri hasta grubunda $\% 68,9$ olarak saptandı $(\mathrm{p}=0.085)$.

Sonuç Geriatrik yaş grubunda hiperglisemi en sık yatış nedenidir. Beslenme bozukluğu tanısı ile yatırılan hastalarda hastane içi ölüm oranı yüksektir. Anemi, geriatrik yaş grubunda sık görülmekte ve hastaneye yatış nedenleri içerisinde de önemli bir yer tutmaktadır. Bu yaş grubunda polifarmasi oranı da yüksektir.

Anahtar Geriatri; Hastanede ölüm; Komorbidite; Malnutisyon; Anemi

Kelimeler

Abstract

Objective We aimed to evaluate the demographic characteristics, reasons for hospitalization, chronic diseases and laboratory results of geriatric patients treated in the Internal Medicine Clinic.

Materials A total of 370 patients aged 65 and over who were hospitalized in the Internal Medicine clinic between January 2015 and December 2017 were included in the study. Demographic data and and Methods laboratory results of the patients were analyzed retrospectively.

Resulrs The most common reasons for hospitalization were hyperglycemia (29.7\%), anemia (15.1\%), pneumonia (10.8\%), acute renal failure (7\%) and malnutrition (6.8\%) respectively. The in-hospital mortality rate was $3.5 \%$ and the most common reason for hospitalization in the deceased patients was malnutrition (38.5\%). In 56 patients hospitalized for anemia, the most common cause of anemia was iron deficiency anemia (62.5\%). The most common chronic diseases were hypertension (72.4\%), diabetes mellitus (62.4\%) and anemia (46.5\%), respectively. Interventional procedures were performed in $15.1 \%$ of the patients. The most common invasive procedure was upper endoscopy with colonoscopy $(n=24,6.5 \%)$. The rate of polypharmacy was $75.7 \%$ in all age groups, and it was found to be $77.9 \%$ in the $65-79$ age group and $68.9 \%$ in the patient group aged 80 and over $(p=0.085)$.

Conclusion Hyperglycemia is the most common reason for hospitalization in the geriatric age group. In-hospital mortality is high in patients hospitalized with a diagnosis of malnutrition. Anemia is common in the geriatric age group and has an important place among the reasons for hospitalization. In this age group, the rate of polypharmacy is also high.

Keywords Geriatrics; Hospital mortality; Comorbidity; Malnutrition; Anemia
} 


\section{GíRiș}

Doğumdan yaşamın ilerlemesine kadar geçen zaman, kronolojik yaşlanma olarak tanımlanmaktadır. Dünya Sağlık Örgütü (DSÖ) 65 yaş ve üzeri bireyleri yaşlı, 85 yaş ve üzerini ise çok yaşlı olarak tanımlamıştır. Geriatristler ise 6574 yaş arasını genç yaşlılık, 75-84 yaş arasını orta yaşlılık, 85 yaş üzerini ise ileri yaşlılık dönemi olarak sınıflamışlardır. ${ }^{1}$ Dünyada yaşam standartlarının iyileşmesiyle birlikte yaşlı nüfusu artmaktadır. Dünyada yaşlı nüfusunun oranının 2050 yılında \%22'lere ulaşması beklenmektedir. ${ }^{2}$ Türkiye İstatistik Kurumunun (TÜIK) son verilerine göre Türkiye'de yaşlı nüfusun toplam nüfus içindeki oranı 1935 yllına göre 2,3 kat artarak 2019 yılında \%9,1'e yükselmiştir. Ülkemiz için nüfus projeksiyonlarına göre yaşlı nüfus oranının 2030 yılında \%12,9, 2040 yılında \%16,3, 2060 yılında \%22,6 ve 2080 yılında \%25,6 olacağı öngörülmektedir. Yaşlı nüfusun \%62,8’i 65-74 yaş arası grupta yer almaktadır. Seksen beş yaş üzeri yaşlı nüfusun oranı ise \%9,1'dir. Kütahya ilindeki yaşlı nüfus oranı ise \%13,1 olarak saptanmıştır. ${ }^{3}$

Yaşlı popülasyonun artmasıyla birlikte bu yaş grubunda sık gözlenen kronik hastalıklar ve bunların tedavileri önemli hale gelmiştir. TÜİK tarafından 2019 yılında yapılan araştırmada, 65 yaş ve üzeri bireylerde ölümlerin \%38'inin dolaşım sistemi hastalıklarından, \%19'unun benign veya malign tümörlerden, \%12'sinin ise solunum sistemi hastalıklarından kaynaklandığı rapor edilmiştir. ${ }^{3}$

Bu çalışmada, İç Hastalıkları Kliniğinde yatarak tedavi gören geriatrik hastaların demografik özelliklerinin, hastaneye yatı̧s nedenlerinin, yatış sürelerinin, kronik hastalıklarının ve laboratuvar sonuçlarının değerlendirilmesi ve hastane içi mortalite nedenlerinin saptanması amaçlandı.

\section{GEREÇ ve YÖNTEMLER}

Tek merkezli, tanımlayıcı tipte ve retrospektif olarak tasarlanan çalışmaya Kütahya Sağlık Bilimleri Üniversitesi İç Hastalıkları Kliniğinde Ocak 2015 ile Aralık 2017 tarihleri arasında yatırılarak tedavi edilen 65 yaş ve üzeri 370 hasta dahil edildi. Hastaların verileri tıbbi kayıtlardan retrospektif olarak değerlendirildi. Hastaların yatış nedenleri, klinik öyküleri, kronik hastalıkları, kullanmakta oldukları ilaçlar, yapılan girişimsel işlemler, hastanede yatış süreleri ve laboratuvar sonuçları kaydedildi. DSÖ kriterlerine göre hemoglobin değerlerinin kadınlarda $12 \mathrm{~g} /$ dl'nin, erkeklerde $13 \mathrm{~g} / \mathrm{dl}$ 'nin altında olması anemi olarak kabul edildi. ${ }^{4}$ Polifarmasi, beş ve üzeri sayıda ilaç kullanımı olarak kabul edildi ve hastaların yatış öncesi kullandıkları ilaç sayısı göz önüne alındı. ${ }^{5}$ Çalışma öncesinde Kütahya Sağlık Bilimleri Üniversitesi Tip Fakültesi, Klinik Araştırmalar Etik Kurulu'ndan onay alındı (Etik kurul tarihi ve protokol numarası 24.07.2019, 2019/08-7) ve çalışma, Helsinki İlkeler Deklarasyonuna uygun olarak gerçekleştirildi.

Çalışma verilerinin analizi için SPSS (Statistical Package for Social Science, sürüm 22) programı kullanıldı. Sürekli değişkenlerin normal dağılıma uygunluğu Kolmogorov-Smirnov ve Shapiro-Wilk testleri ile incelendi. Normal dağılım göstermeyen veriler ortanca ile çeyrekler arası aralık (yüzde 25 ve 75) olarak ifade edildi. Kategorik değiş̧kenler ise sayı ve yüzde olarak ifade edildi. Gruplar arasındaki farklılıklar, normal dağılım göstermeyen veriler için Mann-Whitney U testi ile karşılaştırıldı. Kategorik parametreler Ki-kare testi ve Fisher exact test kullanılarak analiz edildi. $\mathrm{P}<0,05$ tüm testler için istatistiksel olarak anlamlı kabul edildi.

\section{BULGULAR}

Çalışmaya 65 yaş üstü toplam 370 yatan hasta alınmış olup, hastaların 150'si erkek, 220'si kadındı (Tablo 1). Geriatrik yaş grubundaki 370 yatan hastanın 13’ü $(\% 3,5)$ hastanedeki tedavileri sırasında vefat etti. Ölen 13 hasta değerlendirildiğinde en sık yatı̧s nedeni beslenme bozukluğuydu $(\mathrm{n}=5, \% 38,5)$. Hastaneye yatı̧ en çok mart ayında $(\% 11,6)$, en az ise ağustos ayında $(\% 4,9)$ gerçekleşti. En sık hastaneye yatış sebepleri sırasıyla hiperglisemi $(\% 29,7)$, anemi $(\% 15,1)$, pnömoni $(\% 10,8)$, akut böbrek yetmezliği (\%7) ve beslenme bozukluğuydu (\%6,8) (Tablo 2). Cinsiyete göre yatış nedenlerinin dağılımı Şekil 1'de gösterilmiştir. 
Her iki cinsiyet için de ilk 3 yatış nedeni benzerdi. Anemi nedeniyle hastaneye yatırılan 56 hastada anemi nedenleri sırasıyla demir eksikliği anemisi $(\% 62,5)$, kronik hastalık anemisi $(\% 26,8)$ ve kronik böbrek yetmezliğiydi (\%10,7). Anemi nedeniyle yatırılan 56 hastanın 44 'üne $(\% 78,6)$ eritrosit transfüzyonu yapıldı. Demir eksikliği anemisi olan 35 hastanın 20'sine $(\% 57,1)$ alt ve/veya üst gastrointestinal sistem endoskopisi yapıldı.

\begin{tabular}{|c|c|}
\hline Parametre & $\mathrm{n}=370$ \\
\hline Yaş, yıl & $74(69-79)$ \\
\hline Erkek cinsiyet, n (\%) & $150(40,5)$ \\
\hline Hastanede yatış süresi, gün & $8(6-12)$ \\
\hline İlaç sayısı, n & $6,5(5,0-9,0)$ \\
\hline Transfüzyon, n (\%) & $72(19,5)$ \\
\hline Mortalite, n (\%) & $13(3,5)$ \\
\hline Hipertansiyon, n (\%) & $268(72,4)$ \\
\hline Diabetes mellitus, n (\%) & $231(62,4)$ \\
\hline Anemi, n (\%) & $172(46,5)$ \\
\hline Hiperlipidemi, n (\%) & $132(35,7)$ \\
\hline Koroner arter hastalığı, n (\%) & $95(25,7)$ \\
\hline Kronik obstrüktif akciğer hastalığı, n (\%) & $53(14,3)$ \\
\hline Kronik böbrek yetmezliği, n (\%) & $48(13,0)$ \\
\hline Konjestif kalp yetmezliği, n (\%) & $34(9,2)$ \\
\hline Malignite, n (\%) & $26(7,0)$ \\
\hline Hipotiroidi, n (\%) & $25(6,8)$ \\
\hline Atriyal fibrilasyon, n (\%) & $23(6,2)$ \\
\hline Serebrovasküler hastalık, n (\%) & $17(4,6)$ \\
\hline Alzheimer/Demans, n (\%) & $16(4,3)$ \\
\hline Hipertroidi, n (\%) & $15(4,1)$ \\
\hline Astım, n (\%) & $13(3,5)$ \\
\hline \multicolumn{2}{|c|}{$\begin{array}{l}\text { Değerler; yüzde veya çeyrekler arası (yüzde 25-75) aralıklı ortanc } \\
\text { değerler olarak sunulmuştur. }\end{array}$} \\
\hline
\end{tabular}

Tablo 2. Yatış nedenlerinin olgu sayıları ve yüzdesel dağılımları

\begin{tabular}{|l|c|c|}
\hline Yatış nedeni & Olgu sayıs1 & Yüzdesi \\
\hline Hiperglisemi & 110 & 29,7 \\
\hline Anemi & 56 & 15,1 \\
\hline Pnömoni & 40 & 10,8 \\
\hline Akut böbrek yetmezliği & 26 & 7,0 \\
\hline Beslenme bozukluğu & 25 & 6,8 \\
\hline $\begin{array}{l}\text { Kronik böbrek yetmezliğinin akut } \\
\text { alevlenmesi }\end{array}$ & 20 & 5,4 \\
\hline Diyabetik ayak & 19 & 5,1 \\
\hline Üriner sistem enfeksiyonu & 18 & 4,9 \\
\hline Konjestif kalp yetmezliği & 15 & 4,1 \\
\hline Elektrolit bozukluğu & 8 & 2,2 \\
\hline Kronik obstrüktif akciğer hastalığı & 6 & 1,6 \\
\hline Kontrolsüz hipertansiyon & 5 & 1,4 \\
\hline Gastroenterit & 4 & 1,1 \\
\hline Selülit & 3 & 0,8 \\
\hline Anjioödem & 2 & 0,5 \\
\hline Gastrointestinal kanama & 2 & 0,5 \\
\hline Hipoglisemi & 2 & 0,5 \\
\hline Osteoporoz & 2 & 0,5 \\
\hline İntoksikasyon & 1 & 0,3 \\
\hline Karaciğer fonksiyon bozukluğu & 1 & 0,3 \\
\hline Karın ağrısı & 1 & 0,3 \\
\hline Kolanjit & & 0,3 \\
\hline Kolesistit & 1 & 0,3 \\
\hline Romatoid artrit & 0,3 \\
\hline Siroz & 1 & 0,3 \\
\hline & 1 & \\
\hline
\end{tabular}

Toplam 370 geriatrik hastanın 56'sına $(\% 15,1)$ girişimsel işlem yapıldı. Hastalara yatışları esnasında en sık yapılan girişimsel işlem alt ve üst gastrointestinal sistem endoskopisiydi ( $\mathrm{n}=24, \% 6,5)$. Ayrica 9 hastaya alt gastrointestinal sistem endoskopisi $(\% 2,4), 8$ hastaya tiroid ince iğne aspirasyon biyopsisi $(\% 2,2)$ ve 3 hastaya $(\% 0,8)$ üst gastrointestinal sistem endoskopisi yapıldı. Hastalarda en sık görülen kronik hastalıklar sırasıyla hipertansiyon $(\% 72,4)$, diabetes mellitus $(\% 62,4)$ ve anemiydi $(\% 46,5)$. Cinsiyete göre eşlik eden kronik hastalıkların sıklığı karşılaştırıldığında, erkeklerde anemi, kronik obstrüktif akciğer hastalığı (KOAH) ve malignite, kadınlarda hipotiroidi ve bronşiyal astım görülme sıklığı anlamlı olarak daha yüksekti (Tablo 
3). Çalışmamızdaki erkek ve kadın hastaların laboratuvar değerlerinin karşılaştırılması Tablo 4'te gösterilmiştir. Hastalar 65-79 yaş $(n=280)$ ve 80 yaş ve üzeri $(n=90)$ olmak üzere iki yaş grubuna ayrılarak incelendiğinde, 80 yaş ve üzeri hasta grubunda ilaç sayısı, kan transfüzyon gereksinimi, diyabet, hiperlipidemi ve KOAH görülme sıklıkları anlamlı olarak daha düşük bulundu (Tablo 5). Tüm çalışma grubunda polifarmasi oranı \%75,7 olup, 65-79 yaş grubunda \%77,9 ( $\mathrm{n}=218), 80$ yaş ve üzeri hasta grubunda $\% 68,9(\mathrm{n}=62)$ olarak saptand ${ }_{1}(\mathrm{p}=0.085)$. 65-79 yaş grubunda en sık hastaneye yatıs nedenleri sırasıyla hiperglisemi $(\% 33,9)$, anemi $(\% 14,3)$ ve pnömoni $(\% 10,7)$ iken 80 yaş ve üzeri hasta grubunda anemi $(\% 17,8)$, hiperglisemi $(\% 16,7)$ ve beslenme bozukluğuydu (\%12,2) (Şekil 2).

\begin{tabular}{|c|c|c|c|}
\hline Parametre & $\begin{array}{c}\text { Erkek } \\
(\mathrm{n}=150)\end{array}$ & $\begin{array}{c}\text { Kadın } \\
(\mathrm{n}=220)\end{array}$ & $\mathrm{p}$ \\
\hline Yaş, yll & $74,0(68,8-79,3)$ & $74,0(70,0-79,0)$ & 0,842 \\
\hline Hastanede yatış süresi, gün & $9(6-14)$ & $8(6-11)$ & 0,066 \\
\hline İlaç sayısı, n & $6(4-9)$ & $7(5-9)$ & 0,167 \\
\hline Transfüzyon, n (\%) & $35(23,3)$ & $37(16,8)$ & 0,120 \\
\hline Mortalite, n (\%) & $8(5,3)$ & $5(2,3)$ & 0,116 \\
\hline Hipertansiyon, n (\%) & $101(67,3)$ & $167(75,9)$ & 0,070 \\
\hline Diabetes mellitus, n (\%) & $91(60,7)$ & $140(63,6)$ & 0,563 \\
\hline Anemi, n (\%) & $88(58,7)$ & $84(38,2)$ & $<0.001$ \\
\hline Hiperlipidemi, n (\%) & $50(33,3)$ & $82(37,3)$ & 0,437 \\
\hline Koroner arter hastalığı, n (\%) & $45(30,0)$ & $50(22,7)$ & 0,116 \\
\hline Kronik obstrüktif akciğer hastalığı, n (\%) & $28(18,7)$ & $25(11,4)$ & 0,049 \\
\hline Kronik böbrek yetmezliği, n (\%) & $19(12,7)$ & $29(13,2)$ & 0,885 \\
\hline Konjestif kalp yetmezliği, n (\%) & $11(7,3)$ & $23(10,5)$ & 0,308 \\
\hline Malignite, n (\%) & $18(12,0)$ & $8(3,6)$ & 0,002 \\
\hline Hipotiroidi, n (\%) & $5(3,3)$ & $20(9,1)$ & 0,030 \\
\hline Atriyal fibrilasyon, n (\%) & $5(3,3)$ & $18(8,2)$ & 0,058 \\
\hline Serebrovasküler hastalık, n (\%) & $8(5,3)$ & $9(4,1)$ & 0,575 \\
\hline Alzheimer/Demans, n (\%) & $3(2,0)$ & $13(5,9)$ & 0,070 \\
\hline Hipertroidi, n (\%) & $7(4,7)$ & $8(3,6)$ & 0,622 \\
\hline Astım, n (\%) & $0(0)$ & $13(5,9)$ & 0,002 \\
\hline
\end{tabular}


Sakarya Tip Dergisi 2021;11(3):507-515

KiLİT ve Ark., Yatan Geriatrik Hastaların Değerlendirilmesi

\begin{tabular}{|c|c|c|c|}
\hline Parametre & $\begin{array}{c}\text { Erkek } \\
(\mathrm{n}=150)\end{array}$ & $\begin{array}{c}\text { Kadın } \\
(\mathrm{n}=220)\end{array}$ & $\mathrm{p}$ \\
\hline Hemoglobin, g/dL & $12,0(9,9-13,3)$ & $12,1(10,0-13,5)$ & 0,786 \\
\hline $\mathrm{MCH}, \mathrm{pg}$ & $28,0(25,5-29,6)$ & $28,0(26,3-29,4)$ & 0,975 \\
\hline $\mathrm{MCV}, \mathrm{fL}$ & $85,3(79,5-89,4)$ & $85,7(80,3-88,1)$ & 0,968 \\
\hline RDW, \% & $15,5(13,9-17,6)$ & $14,3(13,5-16,3)$ & $<0,001$ \\
\hline Platelet, $x 1000 / \mu 1$ & $246(196-327)$ & $254(200-303)$ & 0,876 \\
\hline Lökosit sayısı, / $\mu \mathrm{l}$ & $8020(6288-10500)$ & $8000(6525-9975)$ & 0,995 \\
\hline Nötrofil sayısı, $/ \mu \mathrm{l}$ & $5300(4075-8103)$ & $5300(3800-7075)$ & 0,582 \\
\hline Lenfosit sayısı, / $\mu \mathrm{l}$ & $1440(1000-2000)$ & $1800(1200-2400)$ & 0,001 \\
\hline Eozinofil sayısı, / $\mu \mathrm{l}$ & $100(0-200)$ & $100(0-200)$ & 0,701 \\
\hline Nötrofil-lenfosit oranı & $3,6(2,4-6,3)$ & $3,2(1,9-4,8)$ & 0,011 \\
\hline Platelet-lenfosit oranı & $170(115-258)$ & $144(98-207)$ & 0,006 \\
\hline Vitamin B12, ng/L & $305(201-541)$ & $334(204-557)$ & 0,513 \\
\hline Ferritin, ug/L & $82(32-177)$ & $56(21-113)$ & 0,005 \\
\hline TSH, mIU/L & $1,0(0,6-1,7)$ & $1,2(0,6-1,9)$ & 0,367 \\
\hline Serbest T4, ng/dL & $1,0(0,9-1,1)$ & $1,1(0,9-1,2)$ & 0,027 \\
\hline Açlık kan şekeri, mg/dL & $152(107-255)$ & $169(108-288)$ & 0,298 \\
\hline Üre, mg/dL & $49(39-73)$ & $48(36-67)$ & 0,408 \\
\hline Kreatinin, mg/dL & $1,2(1,0-1,7)$ & $1,1(0,9-1,5)$ & $<0,001$ \\
\hline Sodyum, mmol/L & $138(135-139)$ & $137(135-140)$ & 0,965 \\
\hline Potasyum, mmol/L & $4,4(4,0-4,8)$ & $4,4(4,1-4,9)$ & 0,274 \\
\hline Kalsiyum, mg/dL & $8,9(8,5-9,2)$ & $9,1(8,6-9,4)$ & 0,017 \\
\hline AST, U/L & $20,0(15,8-29,3)$ & $20,0(16,0-28,0)$ & 0,785 \\
\hline ALT, U/L & $16,0(11,0-25,0)$ & $17,0(12,0-24,0)$ & 0,473 \\
\hline Albumin, g/L & $3,6(3,1-3,9)$ & $3,7(3,3-4,0)$ & 0,004 \\
\hline Total Kolesterol, mg/dL & $156(127-184)$ & $175(142-217)$ & $<0.001$ \\
\hline Trigliserid, mg/dL & $114(84-165)$ & $144(98-204)$ & 0,001 \\
\hline LDL-C, mg/dL & $91(70-112)$ & $102(77-138)$ & 0,008 \\
\hline HDL-C, mg/dL & $36(29-42)$ & $42(34-49)$ & $<0,001$ \\
\hline CRP, mg/L & $23,4(5,3-67,1)$ & $9,0(3,2-29,0)$ & 0,001 \\
\hline \multicolumn{4}{|c|}{$\begin{array}{l}\text { Değerler çeyrekler arası (yüzde 25-75) aralıklı ortanca değerler olarak sunulmuştur. MCH: Ortalama korpüsküler hemoglobini, MCV: } \\
\text { Ortalama korpüsküler volüm, RDW: Kırmızı kan hücresi dağılım genişliği, TSH: Tiroid uyarıcı hormon, AST: Aspartat aminotransferaz, } \\
\text { ALT: Alanin aminotransferaz, LDL-C: Düşük yoğunluklu lipoprotein kolesterol, HDL-C: Yüksek yoğunluklu lipoprotein kolesterol, CRP } \\
\text { C-reaktif protein. }\end{array}$} \\
\hline
\end{tabular}




\begin{tabular}{|c|c|c|c|}
\hline Parametre & $\begin{array}{l}\text { 65-79 yaş } \\
(\mathrm{n}=280)\end{array}$ & $\begin{array}{c}80 \text { yaş ve üzeri } \\
(\mathrm{n}=90)\end{array}$ & $\mathrm{p}$ \\
\hline Yaş, y1l & $72(68-75)$ & $84(82-86)$ & - \\
\hline Hastanede yatı̧s süresi, gün & $8(6-11)$ & $8(6-13)$ & 0,867 \\
\hline İlaç sayısı, n & $7(5-10)$ & $6(4-8)$ & 0,002 \\
\hline Transfüzyon, n (\%) & $43(15,4)$ & $29(32,2)$ & $<0,001$ \\
\hline Mortalite, n (\%) & $8(2,9)$ & $5(5,6)$ & 0,319 \\
\hline Hipertansiyon, n (\%) & $208(74,3)$ & $60(66,7)$ & 0,159 \\
\hline Diabetes mellitus, n (\%) & $194(69,3)$ & $37(41,1)$ & $<0,001$ \\
\hline Hiperlipidemi, n (\%) & $115(41,1)$ & $17(18,9)$ & $<0,001$ \\
\hline Koroner arter hastalığı, n (\%) & $78(27,9)$ & $17(18,9)$ & 0,090 \\
\hline Kronik obstrüktif akciğer hastalığı, n (\%) & $34(12,1)$ & $19(21,1)$ & 0,035 \\
\hline Kronik böbrek yetmezliği, n (\%) & $36(12,9)$ & $12(13,3)$ & 0,907 \\
\hline Konjestif kalp yetmezliği, n (\%) & $22(7,9)$ & $12(13,3)$ & 0,118 \\
\hline Malignite, n (\%) & $19(6,8)$ & $7(7,8)$ & 0,749 \\
\hline Hipotiroidi, n (\%) & $20(6,8)$ & $5(5,6)$ & 0,602 \\
\hline Atriyal fibrilasyon, n (\%) & $19(6,8)$ & $4(4,4)$ & 0,424 \\
\hline Serebrovasküler hastalık, n (\%) & $13(4,6)$ & $4(4,4)$ & 0,938 \\
\hline Alzheimer/Demans, n (\%) & $11(3,9)$ & $5(5,6)$ & 0,552 \\
\hline Hipertroidi, n (\%) & $12(4,3)$ & $3(3,3)$ & 0,927 \\
\hline Astım, n (\%) & $12(4,3)$ & $1(1,1)$ & 0,202 \\
\hline
\end{tabular}

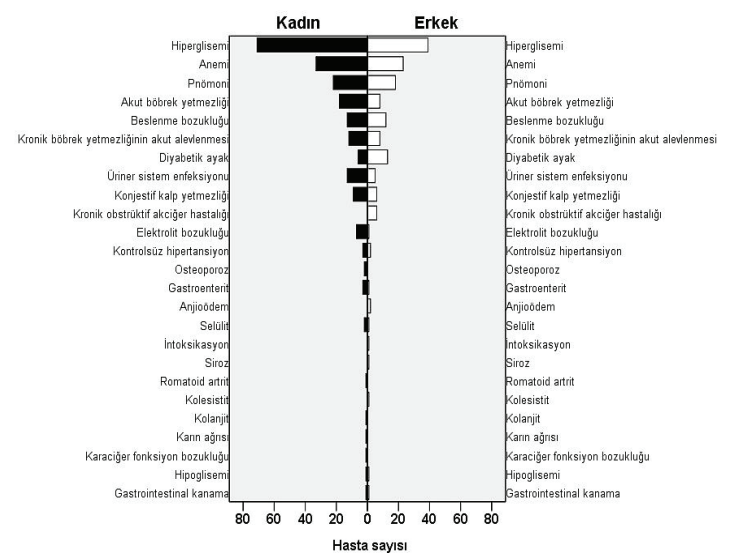

Şekil 1. Cinsiyete göre hastaneye yatı̧s nedenleri.

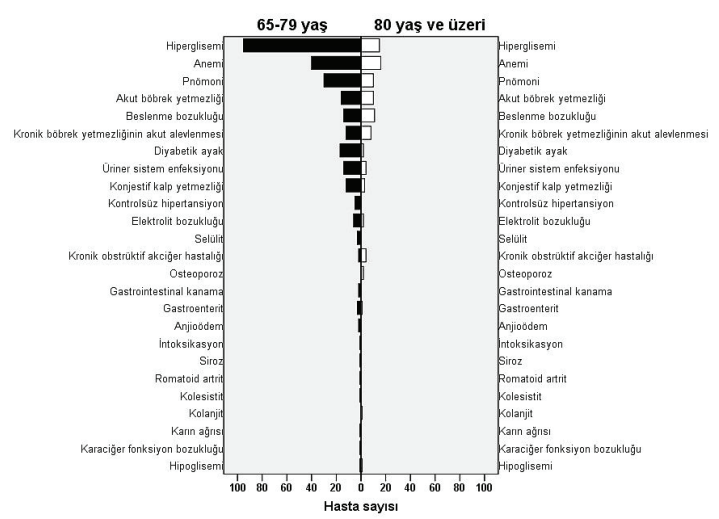

Şekil 2. Yaş gruplarına göre hastaneye yatış nedenleri. 


\section{TARTIŞMA}

Çalışmamızda, hastanede yatarak tedavi edilen geriatrik hastaların yatış endikasyonları, laboratuvar değerleri, mortalite oranları ortaya kondu. TÜİK'in 2019 yılı verilerine göre yaşlı nüfusun \%44,2'sini erkekler, \%55,8'ini kadınlar oluşturmaktadır. ${ }^{3}$ Çalışmamızda ise hastaların \%40,5'i erkek, \%59,5'i kadındı. Çalışma popülasyonunun cinsiyet dağılımı Türkiye nüfus verilerine benzerdi.

Yaşlı nüfusun artması ile kronik hastalıkların yönetimi ön plana çıkmıştır. Yaşlı bireylerde kronik hastalıkların görülme sıklı̆g yüksek olup \%80'inde en az bir ve \%50'sinde en az iki kronik hastalık tespit edilmiştir. ${ }^{6}$ Ülkemizde yapılan bir çalışmada, geriatrik bireylerin \%70-90’ında en az bir kronik hastalık saptanmıştır. Ünsal ve arkadaşlarının yaptığı bir başka çalışmada, 65 yaş ve üzeri bireylerin \%59,2'sinde bir kronik hastalık, \%35'inde iki kronik hastalık, $\% 5,8$ 'inde üç ve üzeri sayıda kronik hastalık olduğu gösterilmiştir.8 Çalışmamızdaki hastalar incelendiğinde hipertansiyon, diabetes mellitus, hiperlipidemi, koroner arter hastalı̆̆ı ve KOAH’in en sık görülen kronik hastalıklar olduğunu görüyoruz. Çakmur ve arkadaşlarının yaptığı çalışmanın sonuçlarına benzer şekilde çalışmamızda da en sık görülen kronik hastalık hipertansiyondur. ${ }^{9}$

Anemi, yaşlılarda en sık hastaneye yatı̧s nedenlerinden biridir. Nalbant ve arkadaşlarının yaptığı çalışmada geriatrik hastalarda hastaneye yatışın en sık nedeni anemi olarak bulunmuştur (\%60). ${ }^{10}$ Çalışmamızda ise anemi, geriatrik hastalarda her iki cinsiyette de hastaneye yatışın ikinci en sık nedeni olarak saptandı. Çalışmamızda anemi nedeniyle yatış sıklığının daha düşük olmasının nedeninin, anemi tanılı hastaların hastanemizde mevcut bulunan gastroenteroloji ve hematoloji gibi kliniklere de yatırllyyor olması olduğunu düşünüyoruz. Gaskell ve arkadaşlarının yaptığ 1 çalışmada hastanede yatan 65 yaş üstü hastaların \%61'inde anemi saptanmıştır. ${ }^{11}$ Çalışmamıza ise bu oran \% 46,5 olarak bulundu. Petrosyan ve arkadaşlarının yaptığı bir çalışmada, hastanede anemi nedeniyle yatan geriatrik hastalarda aneminin en sık nedenleri inflamasyon, kronik hastalık anemisi ve kronik böbrek yetmezliği olarak bulunmuştur. ${ }^{12}$ Sezer ve arkadaşlarının yaptığı bir başka çalışmada hastaneye yatan geriatrik hastaların \%74,4'ünde anemi tespit edilmiş olup en sık anemi nedenleri sırasıyla inflamasyon, kronik böbrek yetmezliği ve demir eksikliğiydi. ${ }^{13}$ Guralnik ve arkadaşlarının Amerika Birleşik Devletleri’nde anemisi olan geriatrik yaş grubunda yaptıkları çalışmada, hastaların üçte birinde kronik hastalık anemisi olduğunu gösterilmiştir. ${ }^{14}$ Çalışmamızda aneminin sebepleri sırasıyla demir eksikliği anemisi $(\% 62,5)$, kronik hastalık anemisi $(\% 26,8)$ ve kronik böbrek yetmezliğiydi $(\% 10,7)$. Geriatrik bireylerde aneminin erken dönemde saptanması, etkin bir şekilde tedavi edilmesi ve yeterli gıda alımının sağlanması, anemi nedeniyle hastaneye yatışları azaltabilir.

Atherton ve arkadaşları, geriatrik bireylerde hastaneye yatışların en sık yaz aylarında, Diehl ve arkadaşları ise mayıs-ağustos ayları arasında olduğunu bildirmişlerdir. ${ }^{15,16}$ Çalışmamızda ise hastaneye yatışlar en çok mart ayında, en az ise ağustos ayında gerçekleşmiştir. Kütahya ilinin karasal iklimin hâkim olduğu bir bölgede olması ve yaz aylarında kırsal bölgelere göç ile birlikte tarım işinin yoğun olması nedeniyle hastaneye yatış daha az olmuş olabilir.

Çalışmamızdaki erkek geriatrik hastalarda kadın hastalara kıyasla kırmızı hücre dağılım genişliği (RDW), nötrofil sayısının lenfosit sayısına oranı (NLO) ve platelet sayısının lenfosit sayısına oranı (PLO) daha yüksek bulundu. NLO ve PLO’nun, inflamatuvar ve kardiyovasküler hastalıklar ile kanserlerde prognoz göstergesi olarak kullanılabileceği gösterilmiştir. ${ }^{17,18}$ Öztürk ve arkadaşlarının yaptığı bir çalı̧̧mada da NLO, erkek geriatrik hastalarda kadın geriatrik hastalara kıyasla yüksek bulunmuş olup NLO’nun yaşlanma ile birlikte arttığı gösterilmiştir. ${ }^{19}$ Çalışmamızda da NLO erkek hastalarda, kadın hastalara göre yüksek bulunmuştur.

Çalışmaya alınan geriatrik hastalardan kaybedilen 13 hasta değerlendirildiğinde en sık yatış nedeni beslenme bozukluğuydu $(n=5, \% 38,5)$. Yaşlı bireylerde birçok faktöre bağlı 
olarak besin alımı azalır ve yetersiz beslenme riski artar. Yaşlanma anoreksisi bu bağlamda çok önemlidir ve birçok sağlık sorununa yol açabilmektedir. ${ }^{20}$ Malnutrisyonun görüme sıklığı evinde yaşayan yaşlılarda \%5-10 iken hastaneye yatırılan ya da huzurevinde kalan yaşlılarda \%30-60'a kadar yükselmektedir. ${ }^{21} \mathrm{Bu}$ nedenle geriatrik hastalar beslenme bozukluğu açısından yakından izlenmeli ve gerekli destek sağlanmalıdır.

Polifarmasi tanım olarak hastanın ihtiyacından fazla ilaç kullanması olarak tanımlanmaktadır. ${ }^{22}$ Polifarmasi, özellikle de geriatrik bireylerde önemli bir sorundur. Polifarmasi, hastanın tedaviye uyumunun azalmasına, ilaç-ilaç etkileşimlerine, yanlış ilaç kullanımına, ilaç yan etkilerine, acil servis başvurularında ve hastaneye yatışlarda artışa neden olmaktadır. ${ }^{23}$ Slovakya'da geriatrik yatan hastalarda yapılan bir çalışmada polifarmasi sıklığı \%60,3 olarak bulunmuştur. ${ }^{24}$ Sekiz farklı Avrupa ülkesinde bakımevlerinde yaşayan geriatrik bireylerde yapılan bir başka çalışmada polifarmasi görülme sıklığ $\% 74$ olarak bulunmuştur. ${ }^{25}$ Cankara ve arkadaşlarının yaptı̆̆ı çalışmada ise, geriatrik yatan hastalarda polifarmasi sıklığ $1 \% 74,52$ olarak bulunmuştur. ${ }^{26}$ Çalışma popülasyonumuzda ise beş ve üzeri sayıda ilaç kullanımı olarak tanımlanan polifarmasi sıklığı \%75 olarak bulunmuştur. Yaş gruplarına göre incelendiğinde 65-79 yaş arasında \%77, 80 yaş üzerinde ise $\% 70$ olarak bulundu. Hem yurt içi hem de yurt dışında yapılan çalışmaların sonuçlarına benzer şekilde çalışmamızda da her iki yaş grubunda polifarmasi oranı yüksekti. Geriatrik hastalarda renal fonksiyonlarda azalma olması ve ilaç-ilaç etkileşimlerin daha sık görülmesinden dolayı polifarmasiden kaçınılması gerekmektedir. Geriatrik hastalarda tedaviler en az sayıda ve en düşük dozda ilaçlarla planlanmalıdir.

Sonuç olarak, geriatrik yaş grubunda hiperglisemi, İç Hastalıkları Kliniklerine en sık yatış nedenidir. Geriatrik yaş grubu diyabetik bireylerde uygun yaşam tarzı değişiklikleri ve diyet ile beraber uygun anti-diyabetik tedavi ile hipergliseminin önlenmesi, yatış gereksinimlerini azal- tabilir. Mortalite oranı yüksek olan beslenme bozukluğu nedeniyle hastaneye yatışların azaltılabilmesi, geriatrik bireylerin gida alımının yakından izlenmesi ve gerektiğinde de desteklenmesiyle mümkün olabilir. Anemi, geriatrik yaş grubunda sık görülmekte ve hastaneye yatış nedenleri içerisinde de önemli bir yer tutmaktadır. Aneminin erken tanı ve tedavisi ile kan transfüzyonu için hastaneye yatış gereksinimi büyük oranda azaltılabilir. Geriatrik bireylerde polifarmasi oranı da yüksek olup bu yaş grubunda ilaç kullanımı gerekli olmadıkça önerilmemelidir.

\section{Çıkar ilişkisi}

Yazarlar herhangi bir çıkar çatışmalarının olmadığını beyan eder.

Yazarlar herhangi bir maddi destek kullanılmadığını beyan eder.

$\mathrm{Bu}$ çalışmada ulusal ve uluslararası etik kurallara uyulmuştur.

Kütahya Sağlık Bilimleri Üniversitesi Klinik Araştırmalar Etik Kurulu, Tarih: 24.07.2019, Karar no: 2019/08-7.

\section{Katkı Oranı Beyanı}

Tüm yazarlar çalışma tasarımına katkıda bulunmuştur. Veri toplama işlemleri Türkan Paşalı Kilit, Aydan Akalın ve Kevser Onbaşı tarafından yapılmıştır. Analiz, Türkan Paşalı Kilit tarafından yapıldı. Yazının ilk taslağı Türkan Paşalı Kilit ve Aydan Akalın tarafından yazıldı ve tüm yazarlar yazının gözden geçirilmesi ve düzeltilmesinde görev aldılar. Tüm yazarlar makalenin son halini okudu ve onayladi. 
Sakarya Tip Dergisi 2021;11(3):507-515

KiLï ve Ark., Yatan Geriatrik Hastaların Değerlendirilmesi

\section{Kaynaklar}

1. World Health Organization, 1984. The uses of epidemiology in the study of the elderly, Report of a WHO Scientific Group on the Epidemiology of Aging. World Health Organization Technical Report Series, Geneva, 706.

2. Kanasi E, Ayilavarapu S, Jones J. The aging population: demographics and the biology of aging. Periodontol 2000 2016;72:13-18.

3. Türkiye İstatistik Kurumu (TÜIK). Türkiye İstatistik Ylllı̆̆ 2019. www.tuik.gov.tr adresinden 05.03.2021 tarihinde ulaşılmıştır.

4. World Health Organization. Nutritional Anaemias. Report of a WHO Scientific Group. Geneva, Switzerland: World Health Organization; 1968. Technical Report Series No. 405:1-40.

5. Linjakumpu T, Hartikainen S, Klaukka T, et al. Use of medications and polypharmacy are increasing among the elderly. J Clin Epidemiol 2002;55:809-817.

6. Centers for Disease Control and Prevention and The Merck Company Foundation. The State of Aging and Health in America 2007. The Merck Company Foundation, Whitehouse Station, NJ 2007. Available at: http://www.cdc.gov/aging/pdf/saha_2007.pdf (Accessed on April 01, 2021).

7. Gülbayrak C, Açık Y, Oğuzöncül AF, Deveci SE, Ozan AT. Yenimahalle eğitim araşttrma sağllk ocağına başvuran yaşllardaki kronik hastallkların sıklğı ve maliyeti. Eurasion J Medicine 2003;35:7-12.

8. Unsal A, Demir G, Çoban-Özkan A, Gürol Arslan G. Huzurevindeki yaşlllarda kronik hastalık sıklı̆̆ı ve ilaç kullanımları. ADÜ Tip Fakültesi Dergisi 2011;12:5-10.

9. Çakmur H, Erem T, Koç M, et l. Kanser Tanısı Alan Geriatrik Olguların Demografik İncelemesi. Türk Geriatri Dergisi 2000;3:11-14.

10. Nalbant A, Varım C, Kaya T, Tamer A. İç Hastalıkları Kliniğinde Yatarak İzlenen 65 Yaș ve Üzeri Genel Dahiliye Hastalarında Tanısal Dağılımın Araștırılması. Sakarya Tip Dergisi 2013;3:181-185.

11. Gaskell H, Derry S, Andrew Moore R, McQuay HJ. Prevalence of anaemia in older persons: systematic review. BMC Geriatr 2008;8:1.

12. Petrosyan I, Blaison G, Andres E, Federici I. Anaemia in the elderly: an aetiologic profile of prospective cohort of 95 hospitalized patients. Eur J Intern Med 2012;23:524-528.

13. Sezer SD, Demir B, Gülle S, Topaloğlu Ö, Akyurt MH. Incidence and Etiology of Anemia in the Hospitalized Geriatric Patients. Tepecik Eğit Hast Derg 2013;23:61-64

14. Guralnik JM, Eisenstaedt RS, Ferrucci L, Klein HG, Woodman RC. Prevalence of anemia in persons 65 years and older in the United States: evidence for a high rate of unexplained anemia. Blood 2004;104:2263-2268.
15. Atherton WG, Harper WM, Ambrams KR. A year's trauma admissions and the effect of the weather. Injured 2005;36:40-46.

16. Diehl AK, Morris MD, Mannis SA. Use of calendar and weather data to predict walk-in attendance. South Med J 1981;74:709-712.

17. Pichler M, Hutterer GC, Stoeckigt C, et al. Validation of the pre-treatment neutrophil-lymphocyte ratio as a prognostic factor in a large European cohort of renal cell carcinoma patients. Br J Cancer 2013;108:901-907.

18. de Jager CP, van Wijk PT, Mathoera RB, et al. Lymphocytopenia and neutrophil-lymphocyte count ratio predict bacteremia better than conventional infection markers in an emergency care unit. Crit Care 2010;14:192.

19. Öztürk ZA, Yesil Y, Kuyumcu ME, Bilici M, Öztürk N, Yeșil NK, et al. Inverse relationship between neutrophil lymphocyte ratio (NLR) and bone mineral density (BMD) in elderly people. Arch Gerontol Geriatr 2013;57:81-85.

20. Cin P, Tanriöver Ö. Geriyatrik popülasyonda yașlanma anoreksisi. Jour Turk Fam Phy 2020;11: 29-40.

21. Vellas BLaque S, Andrea S, Pourhashemi F, Rolland Y, Baumgartner R, Garry P. Nutrition assessment in the elderly. Curr Opin Clin Nutr Metab Care 2001;4:5-8.

22. Tjia J, Velten SJ, Parsons C, Valluri S, Briesacher BA. Studies to reduce unnecessary medication use in frail older adults: a systematic review. Drugs Aging 2013;30:285-307.

23. Zed PJ, Abu-Laban RB, Balen RM, Loewen PS, Hohl CM, Brubacher JR, et al. Incidence, severity and preventability of medication-related visits to the emergency department: a prospective study. CMAJ 2008;178:1563-1569.

24. Wawruch M, Zikavska M, Wsolova L, Kuzelova M, Tisonova J, Gajdosik J, et al. Polypharmacy in elderly hospitalized patients in Slovakia. Pharm World Sci 2008;30:235-242.

25. Onder G, Liperoti R, Fialova D, Topinkova E, Tosato M, Danese P, et al.; SHELTER Project. Polypharmacy in nursing home in Europe: results from the SHELTER study. J Gerontol A Biol Sci Med Sci 2012;67:698-704.

26. Cankara F, Așcl H, Sönmez Y. Universite hastanesinde yatan hastalarn profili, hekimlerin ilaç tercihleri ve polifarmasi varllğı. Süleyman Demirel Üniversitesi Sağllk Bilimleri Dergisi 2015;6:20-25. 